\title{
Handbook of Florida Water Regulation: On-Site Sewage Treatment and Disposal ${ }^{1}$
}

\author{
Michael T. Olexa, Luke D'Isernia, Laura Minton, Dulcy Miller, and Sarah Corbett ${ }^{2}$
}

\section{Preface}

This handbook is designed to provide an accurate, current, and authoritative summary of the principle Federal and Florida laws that directly or indirectly relate to agriculture. This handbook should provide a basic overview of the many rights and responsibilities that farmers and farmland owners have under both Federal and Florida laws as well as the appropriate contact information to obtain more detailed information. However, the reader should be aware that because the laws, administrative rulings, and court decisions on which this handbook is based are subject to constant revision, portions of this publication could become outdated at anytime. Several details of cited laws are also left out due to space limitations.

This handbook is distributed with the understanding that the authors are not engaged in rendering legal or other professional advice, and the information contained herein should not be regarded as a substitute for professional advice. This handbook is not all inclusive in providing information to achieve compliance with the Federal and Florida laws and regulations governing water protection. For these reasons, the use of these materials by any person constitutes an agreement to hold harmless the authors, the Florida Cooperative Extension Service, the Institute of Food and Agricultural Sciences, and the University of Florida for any liability claims, damages, or expenses that may be incurred by any person as a result of reference to or reliance on the information contained in this handbook.

\section{Who Regulates On-Site Sewage Treatment and Disposal?}

While the Florida Statutes contain a set of broad guidelines regulating sewage treatment and disposal, the Florida Department of Health (DOH) is the primary authority for specific, statewide regulations controlling the installation and use of on-site sewage treatment and disposal systems (septic tanks and drain fields).

The installation and use of on-site sewage treatment and disposal systems (OSTDS) also falls

1. This is EDIS document FE614, a publication of the Food and Resource Economics Department, Florida Cooperative Extension Service, Institute of Food and Agricultural Sciences, University of Florida, Gainesville, FL. Published December 2005. Please visit the EDIS website at http://edis.ifas.ufl.edu.

2. Michael T. Olexa, Professor, Food and Resource Economics Department, Florida Cooperative Extension Service, Institute of Food and Agricultural Sciences, University of Florida, Gainesville, FL; Director, Agricultural Law Center, University of Florida, Gainesville, FL; and Chair, Agricultural Law Committee of The Florida Bar. Luke D'Isernia, former student (graduated cum laude in 2005), Levin College of Law, University of Florida, Gainesville, FL. Laura Minton, Attorney, Dean, Mead, Egerton, Bloodworth, Capouano, and Bozarth, Orlando, FL. Dulcy Miller, attorney, Foley and Lardner, LLP, Orlando, FL. Sarah Corbett, Attorney, Florida Second District Court of Appeal, Lakeland, FL.

The Institute of Food and Agricultural Sciences (IFAS) is an Equal Opportunity Institution authorized to provide research, educational information and other services only to individuals and institutions that function with non-discrimination with respect to race, creed, color, religion, age, disability, sex, sexual orientation, marital status, national origin, political opinions or affiliations. U.S. Department of Agriculture, Cooperative Extension Service, University of Florida, IFAS, Florida A. \& M. University Cooperative Extension Program, and Boards of County Commissioners Cooperating. Larry Arrington, Dean 
under the permit authority of the Florida Department of Environmental Protection (DEP) and the Environmental Protection Agency (EPA), under the Clean Water Act (CWA) and the Safe Drinking Water Act (SDWA). This is the case especially when an OSTDS and/or an OSTDS drain field are installed in a wetland, or when the failure (leaking) of an OSTDS would threaten the quality of ground water and/or surface water with contamination, and make public well water unsafe for human consumption.

The EPA can regulate an OSTDS, under the SDWA, as a Class Five Well and require it to meet Underground Injection Control (UIC) Program requirements if either one of the following conditions is met:

1. The OSTDS, regardless of size, receives any amount of industrial or commercial wastewater.

2. The OSTDS receives solely sanitary waste from multiple family residences or a non-residential establishment and has the capacity to serve twenty or more persons per day (also known as large capacity onsewage treatment and disposal systems).

If either condition is met, then the owners or operators of the OSTDS must meet state and at least the minimum federal requirements for Class Five wells as follows:

- Obey the non-endangerment performance standard prohibiting injection that allows the movement of fluids containing any contaminant into underground sources of drinking water if the presence of that contaminant may cause a violation of any primary drinking water regulation or adversely affect public health; and

- Provide inventory information (including facility name and location, legal contact name and address, ownership information, nature and type of injection wells, and operating status of the injection wells) to the state or EPA regional UIC Program.
The waste disposal rules of the Department of Environmental Protection (DEP) will apply as follows:

- The estimated volume of domestic sewage to be processed exceeds 10,000 gallons per day.

- The estimated volume of commercial sewage to be processed exceeds 5,000 gallons per day.

- The water contains or will contain industrial or hazardous waste.

If the system falls into one of these categories, the DEP will likely require a separate permit and impose further restrictions on the system. In addition to the statewide rules, local governments may have more stringent rules and requirements for permitting and regulating the disposal system.

\section{Are On-Site Sewage Treatment and Disposal Systems Acceptable?}

The state does not encourage the use of on-site sewage treatment and disposal systems when the use of public or investor-owned sewage systems is readily available. Both the statutes and the $\mathrm{DOH}$ rules require the use of public or investor-owned sewage systems in areas where they are readily available when the plumbing of a home or business is actually capable of being connected to these systems.

Unless the system is authorized by the utility and is being used to dispose only gray-water, it must be connected to a public sewage system within one year from the date such a public system becomes available in the area.

Gray-water and Black-water are defined as follows:

- Gray-water is residential wastewater from the bathtub, shower, lavatory, laundry, and sink, except kitchen sink waste.

- Black-water is that part of domestic sewage carried off by toilets, urinals, and kitchen drains. 


\section{Where Must an OSTDS Be Placed?}

The location of an OSTDS is a key factor in determining the potential for groundwater damage as follows:

1. The OSTDS must be placed at least 75 feet from private potable wells, multi-family water wells, and surface waters, including lakes, bays, and normally wet drainage ditches.

2. The OSTDS must be placed 100 feet from public potable wells serving a residential or nonresidential establishment having a total sewage flow of less than or equal to 2,000 gallons a day.

3. The OSTDS must be placed 200 feet from public potable wells serving a residential or nonresidential establishment having a total sewage flow of greater than 2,000 gallons a day.

4. The OSTDS cannot be placed under buildings. It must be placed five feet from building foundations, mobile home walls, swimming pool walls, or property lines, except where property lines abut utility easements which do not contain underground utilities, or where recorded easements are specifically provided for the installation of systems for service to more than one lot or property owner.

5. The OSTDS must be placed 50 feet from non-potable wells.

6. The OSTDS must be placed 10 feet from a storm sewer pipe.

7. The OSTDS must be placed 11 feet from water storage tanks in contact with the ground or potable water lines unless such lines are sealed with a water proof sealant within a sleeve of similar material pipe to a distance of at least 10 feet from the nearest portion of the system. The sleeved water line cannot be located within 24 inches of the OSTDS. Potable water lines within 5 feet of the drain-field must not be located at an elevation lower than the drain-field absorption surface. Non-potable water lines must not be located within 24 inches of the system without backflow preventers or check valves being installed on the water line so as to prevent contamination of the water system.

8. The OSTDS must be placed 75 feet from the mean high-water line of a tidal surface water body.

9. The OSTDS must be placed 75 feet from the mean annual flood line of a permanent non tidal surface water body.

10. The OSTDS must be placed 15 feet from the design high-water line of retention areas, detention areas or swales designed to contain standing or flowing water for less than 72 hours after a rainfall.

11. The OSTDS must be placed 15 feet from the design high-water level of normally dry drainage ditches and normally dry individual lot stormwater retention areas.

12. The OSTDS must be placed 15 feet from groundwater interceptor drains.

13. New fill soil used to install mounded septic systems or replace unsatisfactory naturally existing soils (e.g., unsettled ground) is required to be slightly limited in nature and compacted to the density of the surrounding soil.

14. Special standards apply to the placement of systems in limestone soil, which is particularly common in South Florida.

The land use zoning of the area where the OSTDS is to be installed is also crucial. If an area is zoned for industry or manufacturing, the $\mathrm{DOH}$ will closely monitor the system to ensure that it receives no toxic or hazardous wastes. Additionally, the system will not be permitted if a public sewage system is available. The size of the tank and drain field is also prescribed by the rules, which list the minimum sizes of tanks required for every size of residence or other building. The size regulations are based upon the amount of waste the $\mathrm{DOH}$ estimates each type of building will generate. The size and characteristics of the land on which the tank and drain field are to be installed is also prescribed by the rules which state that the land must be at least twice the size of the drain field itself. 


\section{How Should Systems Be Maintained?}

The owner of the property is responsible for maintenance and upkeep of the system. It is important to note that an OSTDS must be operated under the terms of the rule and permit under which it was approved. The owner may not make any changes to the structure or to the system or increase sewage flow without approval from the local health department. Under DOH rules, the owner should have the level of the tank checked a minimum of once every three years by a licensed septic tank contractor. A licensed contractor should also perform any necessary maintenance to the system. If garbage grinders or commercial sewage are being discharged into a tank, the owner needs to have the system inspected by a licensed septic tank contractor or plumber once a year. Both the statute and the rules prohibit the use of organic chemical solvents, toxic or hazardous chemicals, or petroleum products to degrease or de-clog the system. A licensed contractor must be issued an annual service permit prior to the removal of septage from any OSTDS.

\section{What Are the Procedures for Septic Tank Abandonment?}

A permit and fee are required from the $\mathrm{DOH}$ to abandon a septic tank, and these steps must be followed:

1. The tank should be pumped out.

2. The bottom should be opened or ruptured to prevent water retention.

3. The tank should be filled with clean sand or other suitable material and completely covered with soil.

4. An inspection of the system abandonment shall be conducted by the $\mathrm{DOH}$ or by the local utility or plumbing authority performing the system abandonment.

\section{What Permits and Fees Are Required?}

The $\mathrm{DOH}$ requires a permit for the installation, operation, repair, alteration, modification, replacement, or abandonment of all on-site sewage systems. Prior to the issuance of any permit, an application and a site investigation is required on all sites by the $\mathrm{DOH}$, Florida licensed professional engineers, or other authorized persons. The DOH will also require an inspection of the entire septic system before burial.

The DOH attempts to perform all inspections within one working day after they have been notified that the tank installation is complete. A fee will be collected for the permit, the inspections, and any other necessary services performed by the DOH. Generally, the fees range from $\$ 50$ to $\$ 200$, but can be as high as $\$ 500$ for an application fee for innovative product approval.

It is essential to note that local governments may have separate requirements, including separate permits (e.g., plumbing permits), that may be more stringent than state law or rule. In many cases, the issuance of these permits will be contingent upon the applicant having already obtained a $\mathrm{DOH}$ permit.

\section{When and What Alternative Systems Can Be Used?}

When approved by the DOH county health department, alternative systems may, at the discretion of the applicant, be utilized in circumstances where standard subsurface systems are not suitable or where alternative systems are more feasible. The rules give the individual county health departments as part of the DOH the authority to approve alternative on-site systems such as mounds, gravity sewers, low pressure pipe, and other systems so long as the county feels there will be no adverse effects. However, any approvals of alternative systems must comply with applicable rule and law. The DOH county health department may require the submission of plans prepared by an engineer registered in the State of Florida prior to considering the use of any alternative system. The DOH retains authority to approve the use of temporary measures such as 
portable toilets as well. The DOH rules also create a

Variance Review and Advisory Committee to hear requests for variances. The committee may advise the $\mathrm{DOH}$ to grant a variance when it deems strict compliance with the laws and rules governing on-site sewage treatment and disposal systems cannot be met. However, only DOH has the authority to grant a variance.

\section{Source}

Chapter 381, Florida Statutes, Section 381.0065; Chapter 64E-6, Florida Administrative Code

\section{Contact Information}

OSTD Management (FE616, Contact Agencies)

- S-5, Florida Department of Health (contacting the local county health department may be sufficient)

\section{Acknowledgments}

The authors are indebted to the personnel of both state and federal agencies who provided their time and advice in the preparation of this handbook. The authors are especially indebted to Richard Budell of the Office of Agricultural Water Policy of the Florida Department of Agriculture and Consumer Services for providing funds for the development of this publication. 